

\title{
Gendering Welfare State Analysis: Tensions between Care and Paid Work
}

Ciccia, R., \& Sainsbury, D. (2018). Gendering Welfare State Analysis: Tensions between Care and Paid Work. European Journal of Politics and Gender, 1(1-2), 93-109. https://doi.org/10.1332/251510818X15272520831102

\author{
Published in: \\ European Journal of Politics and Gender
}

\section{Document Version:}

Peer reviewed version

Queen's University Belfast - Research Portal:

Link to publication record in Queen's University Belfast Research Portal

\section{Publisher rights}

(c) 2018 Bristol University Press.

This work is made available online in accordance with the publisher's policies. Please refer to any applicable terms of use of the publisher.

\section{General rights}

Copyright for the publications made accessible via the Queen's University Belfast Research Portal is retained by the author(s) and / or other copyright owners and it is a condition of accessing these publications that users recognise and abide by the legal requirements associated with these rights.

Take down policy

The Research Portal is Queen's institutional repository that provides access to Queen's research output. Every effort has been made to ensure that content in the Research Portal does not infringe any person's rights, or applicable UK laws. If you discover content in the Research Portal that you believe breaches copyright or violates any law, please contact openaccess@qub.ac.uk. 


\title{
Gendering Welfare State Analysis: Tensions between Care and Paid Work
}

\author{
Rossella Ciccia and Diane Sainsbury \\ Forthcoming in European Journal of Gender and Politics
}

\section{Introduction}

The welfare state represents a key interface between economic and political systems and forms of gender relations and power. Its development was premised on particular forms of economy (industrial capitalism), polity (andrarchies, that is, government by men), family (heterosexual nuclear models) and division of labour (male breadwinner) that resulted in women's exclusion from full participation in the public sphere. Welfare states and associated notions of citizenship based on an ideal male worker reinforced women's financial dependence on men by limiting their social rights and ability to make claims to public resources. Women's lesser social rights often came together with weaker substantive political rights and represented a barrier to their full citizenship. By focusing on state-market relations and social provision relating to the sphere of production, mainstream analyses of welfare states were also cast in these masculine principles although, framed in formally gender neutral terms -which relegated women and gender to obscurity.

In this context, the emergence of research on gender and the welfare state constituted an important reorientation. First, feminists broadened notions of social provision to also include measures related to reproduction (Shaver 1994; Lewis 1992) and expanded the notion of social citizenship to incorporate care (Knijn and Kremer, 1997; Lister, 1997; Siim, 2000). They called attention to the family and its relationship with the state and the market in the production of public welfare (Daly and Lewis, 2000; Orloff 1993). They have been at the forefront in bringing in the influence of ideas, discourses and ideologies alongside political ideologies (Author's own 1996; Duncan and Edwards, 1999; Lewis, 1992). They revealed the importance of gender in shaping the politics of welfare states (Author's own, 1999; Koven and Michel, 1993; O'Connor et al. 1999; Skocpol, 1992). So many and multifaceted have been feminist contributions to the study of welfare states that they have fundamentally reshaped the key analytical constructs used in its analysis.

Feminist analysis of welfare states has now established itself as a vibrant area of research, and gender concepts and perspectives have become increasingly part of the everyday language with which researchers and policy-makers talk about social policy. Growing political concerns about women's employment, work-family reconciliation, care deficits, ageing populations and children's outcomes have also contributed to put gender high on the research agenda, and instances of collaboration between gender and non-gender scholars are increasingly observable (Orloff and Palier, 2009; Béland and Mahon, 2016). The distance between feminist and mainstream academic 
communities is now apparently smaller, and the value of gender perspectives is clearly recognized by mainstream researchers. Nonetheless, notions of care, dependency and reproduction still hold an ambiguous place in mainstream analyses (Orloff, 2009a).

Issues about the place and respective value of care and paid work create divisions among feminist welfare state scholars. At the core of this literature is a strong normative concern about altering the unequal gendered division of labour, but there is also disagreement about the best way in which this is to be achieved. For many feminists paid work, and the economic independence it provides, is the precondition of women's liberation (Orloff, 1993). Yet, others insist that gender equality requires that social rights should be attached to care (Knijn and Kremer, 1997). Much of the history of gender and welfare state analysis can be characterized as a pendulum oscillating between those different principles. As Ruth Lister (1997: 178) writes, 'we are torn between wanting to validate and support, through some form of income maintenance provision, the caring work for which women still take the main responsibility in the private sphere and to liberate them from this responsibility so that they can achieve economic and political autonomy in the public sphere'.

The article provides an overview of comparative research on gender relations and the welfare state through the lens of the tensions between care and paid work. First, we discuss how the intellectual enterprise of gendering welfare state analysis emerged and how it shifted feminist views of the welfare state. Secondly, we devote major attention to the comparative turn in feminist analysis of welfare states, the research agenda it established and the major reorientation it produced on mainstream studies. In sections three and four, we turn to the centrality of care in feminist theorizing on the welfare state and the normative perspectives that have tried to overcome the tensions between care and paid work as alternative routes to gender equality. In section five, we illustrate how this tension has shaped women political activity in the welfare state. We conclude by identifying the emerging challenges which need to be addressed by future research.

\section{Bringing Women and Gender In}

To bring gender into the analysis feminist scholars initially focused on women and their relationships to the welfare state. A prevailing view maintained that women were the objects of policy. Women's relationship to the welfare state was characterized as one of dependency, and in its most extreme form, the state was an instrument of women's oppression (Wilson 1977). Other analytical perspectives, adopting 'claims' and 'statuses' as starting points, transformed women into actors - as claimants, beneficiaries, employees and citizens (Peattie and Rein 1983; Hernes 1987). Women's relationship to the welfare state as mothers was also examined. In short, the strategy of focusing on women made women visible in the welfare state where they previously were invisible.

Including women made it possible to compare women and men, which revealed a gender division of welfare and differentiation in social rights. Breaking down the poor by gender disclosed the feminization of poverty (Pearce 1978). This phenomenon reflected the duality of the welfare 
system that differentiated between women and men in terms of type of social entitlement, benefit levels, political legitimacy of social rights, and administrative intrusion in private lives (Nelson 1990).

Finally, the strategy of bringing women into the analysis exposed the male bias in assumptions, concepts and theories. A case in point is T.H. Marshall's social citizenship (1950), one of the most important concepts in the welfare state literature. The concept of social citizenship put social rights on a par with civil and political rights in attaining full citizenship, and Marshall underlined that social rights had the potential to strengthen the capacity to exercise political rights. Feminists criticized Marshall's description of the evolution of civil, political and social rights on the grounds that it did not fit women's historical experience (Hernes 1987: 27). Especially damaging to women's social citizenship was that Marshall's conceptualization upheld a division between the public and private spheres (Pateman 1988). Since being in the public sphere was for Marshall the precondition for social rights, women in the private sphere were denied equal rights, and their rights were derived from their husband's rights and activities in the public sphere.

Summing up, the discussion on women's relationships to the welfare state was initially dominated by perceptions of women as powerless but gradually they were endowed with varying degrees of political agency. The discussion also underscored the importance of the state as an arena of women's activism, and famously Helga Hernes hailed the possibility of 'a woman-friendly state' (1987: 15). This challenged many feminists' aversion to the state and the view that the welfare state was inevitably patriarchal. The universal thrust in theorizing also weakened as feminists from different national contexts critiqued one another's ideas and claims, calling attention to differences between welfare states. The changing perceptions of women's ties to the welfare state set the stage for rethinking the analysis of gender and welfare states.

\section{Gendering Comparative Welfare State Analysis}

While feminist theorizing on the welfare state had been cast in universal terms, welfare state studies had taken a comparative turn in the 1980s, but women and gender relations were conspicuously absent from the analysis. In this context, several feminist researchers independently of one another identified a major gap in the literature, which triggered an important reorientation - the comparative analysis of gender relations in the welfare state. A major focus of the new research agenda was the mutually constitutive nature of gender relations and welfare states. Among the core questions were: How are gender relations encoded in welfare state policies? Do policies reinforce existing gender relations or do they open possibilities of change? What is the nature of the gender division of welfare? Understanding the dynamics between gender and welfare states required attention to both variations and similarities in how different welfare state policies shape gender relations and the politics behind the policies.

Since the 1990s, the concept of welfare regimes dominated the study of welfare states. While early scholarship had been based on generic notions of the welfare state emphasizing commonalities among national experiences, welfare regimes analysis brought to the fore the 
importance of cross-national variation and the idea of different welfare state types characterized by different principles and norms providing a specific policy logic and regularities in policy outputs. Especially influential has been Gøsta Esping-Andersen's typology constructed on the basis of three dimensions: 1) state-market relations; 2) the stratifying effects of welfare state policies; 3) decommodification, or - the ability to 'uphold a socially acceptable standard of living independently of market participation' (1990: 37). Esping-Andersen's work gave rise to a bourgeoning typology industry, but also spurred a forceful feminist critique of his failure to consider the role of the family as provider of welfare, and the unequal gender division of labour and its effects on women's ability to claim many decommmodifying benefits (e.g. unemployment and pension insurance). By focusing on social provisions most relevant for the (male) citizenworker, Esping-Andersen neglected the social rights of citizens who were financially dependent on other family members, the vast majority women (Razavi, 2007).

These criticisms laid the foundations of feminists theorizing on qualitative variations in the way gender inequalities were institutionalized in national welfare systems. The first task was to rethink the fundamental properties of welfare states by formulating key gender-sensitive dimensions of variation. First, the inclusion of the family, and later civil society, alongside the state and the market in social provision underscored the necessity to devote attention to the unequal gender division of paid and unpaid work. A second dimension considered the degree to which stratifying effects of social provision reinforced gender hierarchies by creating tiers of higher paying benefits privileging full-time paid work. The principles of entitlement formed a third dimension, that is, whether social rights were attached to the individual or based on family relationships and marital status. Applying a gender lens to this dimension also brought into focus the principles of maintenance and care - and their impact on women's social rights. A fourth dimension was access to paid work providing women both with means of economic independence and eligibility to workrelated benefits. Other aspects to be considered here are the extent of state effort in ameliorating problems of vertical and horizontal segregation and pay differentials.

In combining these dimensions in new analytical frameworks, feminist adopted two broad approaches: 1) building gender into existing constructs, or 2) separating gender out by constructing new frameworks. The most influential example of the first approach was Ann Shola Orloff's framework (1993) that built gender into Esping-Andersen's typology. Two of this typology's main dimensions were refashioned to include: 1) the nexus between the family, state and market, and 2) gender stratification in types and levels of benefit. However, the problematic nature of decommodification in relation to women and the gender division of labour made it necessary to add two other dimensions to capture the emancipatory potential of social provision on gender relations: access to paid work and the capacity to form and maintain an autonomous household. A major strength of this approach is that by engaging directly with mainstream theories, it promoted dialogue between feminist and mainstream researchers.

The point of departure of the second approach was the construction of gender policy models or regimes based on the gender division of labour (Crompton, 1999; Lewis, 1992, Author's own, 1999). Jane Lewis (1992) argued that the idea of the male breadwinner family had cut across all 
modern welfare states, but that this model had been subsequently modified in different ways across countries. At the core of her analysis was the structure of women's entitlements- as wives/mothers or workers - which was used to identify the variety of gender ideologies and models of division of labour inscribed in national welfare states.

Another important example of this approach is the concept of defamilialization. Lister (1997) formulated defamilialization in response to the inadequacies of decommodification to bring attention to the importance of relations of dependence within the family, that is, individuals' dependence on care provided by family members and financial dependencies within the family. Welfare states pattern these relations by enforcing particular sets of social rights and obligations attached to certain status within the family. Hence, this framework was also focused on the structure of entitlements, but drew attention to the distinction between individualized and familialized rights (Author's own, 1996). This definition left scope for the analysis of all forms of family dependency, including intergenerational ones (Leitner and Lessinich, 2007; Saraceno, 2010).

A rich body of research has developed on the basis of this scholarship. The scope of analyses carried out in this tradition was typically broad and encompassed all sectors of the welfare state including those that had been the stronghold of mainstream analysis (social assistance, pension and unemployment insurance). Researchers working in this tradition both extended the analytical frameworks and the geographical coverage of previous typological works to regions beyond the western world (An and Peng, 2016; Blofield and Franzoni, 2015; Chau and Yu, 2013; Javornik, 2014; Saraceno, 2016; Yu et al., 2015). The blossoming of research on emergent welfare states has generated insights which are frequently germane to the established welfare states, creating a new dynamic in the exchange of ideas and research results. The gendering of welfare state research also initiated a conversation between mainstream and feminist scholars which has benefited both fields and produced great theoretical and methodological innovation. Nonetheless, the task of integrating gender into welfare state analysis is far from achieved. If the mainstream is now infused with gender awareness, care is still often considered only instrumentally in relation to its significance for the economic system and its contribution to human capital development.

The concept of defamilialization is a good example of the tendency in mainstream research to consider care as subordinate to paid employment rather than incorporating the two on equal terms into social and political citizenship. Defamilialization has gained a prominent position in comparative analyses, but in this process it has also undergone a significant shift in meaning, and especially after Esping-Andersen (1999) used it to revise his earlier analysis of welfare regimes. Feminists used defamilialization as synonymous with individualization or the ability to make claims on the state independently of one's position within the family, thus emphasizing the importance of considering care and family dependency at par with others the principles of entitlement. However, when Esping-Andersen used defamilialization - without properly crediting feminists -he focused on the importance of the availability of care outside the home - in particular, childcare. This was considered an essential prerequisite of women's commodification (being in paid employment), and thus their ability to claim social rights based on their status as workers 
(commodification), in this way re-establishing the superiority of work over other entitlements. In his work, care is conceptualized negatively as a burden to families and an obstacle to women's economic independence, and feminist insight about care as an essential obligation and entitlement of citizens has been lost in translation.

In subsequent analyses, defamilialization has been used less to investigate women's position vis-a-vis the entire welfare state and more to analyse family policies. Nonetheless, conceptualizations and measurements of defamilialization have varied widely between studies, and recently, several authors have underscored the need to reassess the extent to which defamilialization is still useful for the analysis of gender relations in the welfare state (Daly, 2011; Kurowska, 2016). In the next section, we focus on feminist contributions that have made care the starting point from which to analyse the dynamics between the system of social provision and gender relations.

\section{Care and Welfare State Analysis}

Although care is central to feminist understandings of the welfare state, care remained undertheorized in the first efforts to gender welfare state. Care was equated with unpaid work in the family (Lewis 1992), thus overlooking the expansion of welfare states in social reproduction and the growing number of benefits attached to the principle of care (maternity and parental benefits, care allowances, benefits for solo mothers, care credits in pension and unemployment schemes). Nor was there an acknowledgement of the ethic of care as a feature of the good society (Tronto, 1993), or the argument that care and reproduction are prerequisites for human and social wellbeing and the very survival of societies.

In response, several feminists advocated a comprehensive concept of care and underlined its centrality in the welfare state project. In critiquing the conception of care as unpaid work, Jane Jenson envisioned an analysis of 'the gender division among caregivers, gender differences in the capacity or need to pay, and the gender consequences of different institutional arrangements for provision' (1997: 187). The existence of a vast range of policies with regard to care - including the crucial role played by social services which had been neglected by the mainstream focus on transfers - prompted feminist to systematize these difference in distinct care regime models (Anttonen, and Sipilä, 1996; Bettio and Plantega, 2008; Leon, 2014). An additional avenue focused on citizenship, elaborating on care related rights (i.e. the right to receive care, the right to care, and the right not to care), which made care recipients visible in the analysis of care where the perspective of caregivers have generally dominated (Knijn and Kremer 1997).

Gender analyses of care have not only focused on state policies, but also looked at the role of other actors. Daly and Lewis (2000) distinguished between social care, the societal organization of care, and care or caring that focuses on the relationships between caregivers and those receiving care. Using this distinction, they developed a multilevel framework where the macro-level explicitly linked care to the political economy of the welfare state, and the micro-level involved individuals and families. In many respects their framework is a specification of the nexus between 
the state, family, and market with the addition of the voluntary sector. Others (Evers et al.,1994; Razavi, 2007) developed the concept of welfare diamond - as opposed to the traditional welfare triangle (state-market-family) - to emphasize the importance of care providers such as charities and community organizations. However, studies also highlighted the emergence of a corporate care industry, including multinational firms, and the ongoing marketization of both childcare and elder care in many countries, including those with long traditions of public direct provision such as the Scandinavian countries (Brennan et al. 2012; Farris and Marchetti, 2017). In this context, the quality of care and the working conditions of paid carers - the majority of which are women remain controversial political issues.

The expanding literature on care and immigration in the wake of globalization demonstrates that the social organization of care is also inextricably linked with other relations of inequality, in particular ethnicity and class (Razavi, 2007; Michel and Peng, 2012). Globalization has led to profound changes in the international division of labour, and, as feminists have noted, the changes pertain not only to production but also to reproduction. Through migration a transnational transfer of caregiving has occurred. While studies initially focused on the interplay between the global and local levels (Parreñas 2001), the attention has eventually shifted to the dynamics between welfare state policies and immigrant women care and domestic workers across countries ${ }^{1}$. Comparative studies on care and labour market policies have revealed the significance of policy variations in the development of informal care markets where immigrant workers are a growing supply of labour (Williams and Gavanas 2008; Simonazzi 2009). Informalization in turn produces new inequalities in the receiving societies by limiting the social rights of immigrant care workers and their access to social benefits. Care provided by immigrant women also has repercussions for the gender division of labour in families and societies, and this type of care can both support and undermine policies aiming to promote gender equality. The transfer of informal care to immigrant domestic workers in the home allows wives, mothers and daughters to join the workforce, but it also reaffirms the home as the site of care and the gendered nature of care since caring tasks and household chores remain largely in the hands of women. It also counteracts the sharing of care among women and men. In this way, these care arrangements challenge feminist visions of transforming the unequal gender division of labour and reproduce this division along class and ethnicity lines.

In sum, feminist research enhanced our understanding care and the way in which welfare regimes dovetail with particular regimes of care, migration and labour regulations. Nonetheless, the emphasis on care might have sidelined issues of paid work. In the next section, we turn to normative perspectives that have tried to reconcile these different principles in elaborating gender equality visions and goals of the welfare state

\footnotetext{
${ }^{1}$ Fiona Williams $(2011,2017)$ has formulated a comprehensive analytical framework that centres on multiple levels and intersections to analyse cross-national and historical diversity in the relationship between migration and care.
} 


\section{Normative perspectives on gender equality, work and care}

The comparative turn in gender and welfare state analysis brought a stronger emancipatory and prescriptive thrust to feminist theorizing on the welfare state. Among the aims were women's full citizenship (Lister, 1997; Siim, 2000), women's (financial) autonomy (Orloff 1993; O'Connor 1993), gender equity (Fraser, 1994) and increasingly over time gender equality (Author's own, 1996, 1999; O'Connor, et al. 1999). In recent years, we have witnessed a rekindling of efforts to define gender equality ideals that reconcile tensions between the desire to place value on care and other unpaid work and the importance of women's labour market participation. This division is rooted in longstanding feminist debates about sameness vs. difference models of women's citizenship, that is, whether gender equality requires that women be treated just like men or that their differences are recognized and provided for.

Dissatisfied with persisting gender inequalities even in the most advanced welfare states, some have turned to utopian thinking. Nancy Fraser's work (1994) on the universal caregiver ideal has often been taken as a point of reference ${ }^{2}$. This ideal envisions a society in which gender roles are transformed inside and outside the labour market so that care is no longer something that only women do. This idea had a strong impact on the field because it identified a third possibility to sameness vs. difference: transforming men to become more like women are, that is, primary caregivers. In Fraser's model the redistribution of care and paid work is also inextricably related to the recognition of the value of care (no longer coded as feminine) ${ }^{3}$. Fraser's work has had a tremendous influence on feminist theorizing on social citizenship (Lister, 1997; Lewis and Giullari, 2005). Others have tried to translate the universal caregiver into a set of policy measures (Author's own, 2012; Author's own, 2014; Gornick and Meyers, 2009; Rubery, 2015). These policy proposals emphasize the importance of giving care rights to men as well as the broader transformation of workplaces and working hours to facilitate the sharing of caring responsibilities between men and women. This strand of literature has been important in making men visible in the analysis of care.

The identification of a single normative ideal is not without problems. Orloff (2009), for instance, criticizes this strategy as too rigid to take into account the sheer diversity of women's interests and the specificities of diverse cultural and political contexts. In her view, the process of defining a gender utopia is essentially an inductive one, one that cannot be understood separately from the specific mobilizations and politics going on in particular contexts. Her main criticism is of method, and concerns the way in which goals emerge and the democratic accountability of this process, but she also points out the limitations of a strategy that leaves the socio-cultural embeddedness of gender roles unaccounted for. Although Orloff does not want to lay out an alternative utopia, she argues for an egalitarian vision that accommodates different kinds of

\footnotetext{
${ }^{2}$ Although the principles of this model were first described in Fraser (1994), she coined the label universal caregiver only in a later version (1997).

${ }^{3}$ In Fraser's model the emphasis is on men equally sharing caregiving from which all other necessary changes including those in the world of work - will follow. Nonetheless, questions remain with regard to power imbalances between the genders in negotiating care work and the possibility of 'horizontal' discrimination between individuals with and without caring responsibilities.
} 
peoples, including those who would not chose a 50/50 sharing of work and care even if they could. She underscore the importance of expanding opportunities and removing obstacles that impede men's and women's ability to make genuine choices about paid work and care. This principle moves in the direction of the capability approach.

The capability approach (CA) was first developed in the context of research on human development (Sen, 1992), and has since made considerable inroads into gender and social policy research (Hobson, 2013; Kurowska, 2016; Lewis and Giullari, 2005). The core claim of CA is that judgements about gender equality should not be based on the distribution of resources, but on the real opportunities that people have to choose things they value (Robeyns, 2005). In the context of work and care, this might entail how much control one has to move between part- and full-time work, or the possibilities that a man or woman have to stay at home and take care of their child. Choice and agency are central in the CA, but so are institutional and socio-cultural norms shaping them. One of the key advantages of the CA as a normative framework is that it emphasizes how the real freedom to choose between paid work and care requires that a comparable value be attached to both (Lewis and Giullari, 2005). Moreover, and in contrast to Fraser's framework, CA provides a model of equality which recognizes the existence of both diverse preferences and inequality of conditions among women. It thus shows greater affinity with an intersectional approach to gender (Hobson, 2013). The application of the CA to gender analysis of welfare states has proven challenging (Korpi et al., 2013; Javornik and Kurowska, 2017), and some of its most promising applications have been in the field of worklife balance. In this view, Hobson (2013) has proposed one of the most comprehensive framework of factors shaping gender agency inequalities. It includes individual characteristics, institutional factors relating to the configuration of welfare states and workplaces, and societal factors such as gender norms, media discourses and social mobilizations. Hobson's framework clearly demonstrates the complexities of applying the CA to issues of agency concerning paid work and care. From a policy perspective, it is also interesting to observe the high degree of overlap in terms of recommendations derived from the CA and the universal caregiver ideal, whereby the main differences concern the greater emphasis within the $\mathrm{CA}$ on differences between women and the importance of modifying the cognitive and cultural coding of gender roles.

The frameworks illustrated here are not exhaustive of the variety of normative ideas advanced by feminist scholars of the welfare state, but they are emblematic of efforts to overcome opposition between paid work and care. Nonetheless, one of the limitations of the normative approach is that it does not engage with the actual power struggles in societies shaping the politics of welfare states.

\section{Gendering the politics of the welfare state}

The gendering of welfare state analysis not only involved the content of policies but also its politics, which raises the issue of women's political agency and possibilities to influence policies. Since welfare state policies allocate resources, a major facet of welfare state politics concerns distributional struggles. Typically distributional struggles have been conceptualized in class terms 
as struggles between labour and capital (Korpi 1980; Esping-Andersen 1990), obscuring women's involvement in welfare state politics. Gendering welfare state politics required rethinking distributional struggles to include gender relations. Central to this type of struggle is the gender division of labour in the family and society involving both production and reproduction and the way it is influenced by policies allocating resources. At a micro-level of the family, a married woman's independent income from paid work and social benefits enhances her bargaining power in making household decisions, and also provides the possibility to exit an unhappy marriage. At a macro-level, policies affecting production and reproduction can alter the unequal gender division of labour. These policies can also change bargaining power in the family (Iversen and Rosenbluth 2010). The outcomes of gender-related distributional struggles can be read off cross-national variations in women's and mothers' contribution to household income, the proportion of women entitled to social benefits based on labour market participation, enrolment rates in childcare, and proportion of men and fathers receiving care-related benefits.

The first wave of women's activism focused on maternal and child welfare, but women also demanded financial independence through access to employment, better working conditions, and equal pay. Thus, from the start, women's activism in welfare state politics encompassed issues of reproduction and production, generating tensions between care and work; the priority assigned to measures related to reproduction or to production divided women. The division deepened as conflicts over difference/equality intensified between equal rights feminists and maternalist feminists advocating measures acknowledging women's differences (Wikander et al. 1995). Of importance, feminist movements continued to wrestle with these conflicts, and the first wave of welfare activism created legacies that later affected women's priorities, policy alliances and strategies.

To what extent have women been active in shaping policies influencing the redistribution of resources and social rights? How have women and feminist actors influenced social policies, and under what circumstances? Among the examples of women's influence are maternal endowments, family allowances, and work-family policies. In many instances these measures introduced social rights based on the principle of care. Cross-class coalitions of women backed maternal endowments in several European countries (Bock and Thane 1991; Koven and Michel 1993), whereas the pattern of women's organizing and framing were important in the adoption of mothers' pensions in the USA (Skocpol 1992). Looking at family allowances, we find that the interwar and post-war periods were characterized by different politics and different combinations of circumstances. In the post-war period a decisive combination promoting the adoption of family allowances included strong working-class movements and women's participation in left parties in countries without large Catholic populations (Misra 2003). In comparing the introduction of workfamily policies in France, the Netherlands, Sweden and the United States, Kimberly J. Morgan (2006) concludes that feminists were primarily important as agenda setters, bringing the issues of mothers' employment and childcare onto the agenda. In this policy area, international organizations, such as the European Union and the United Nations and its specialized agencies, in 
particular, the ILO, have provided new arenas for feminist activism (Kantola 2010; Fish and Shumpert 2017).

A full assessment of women's political agency in welfare state politics requires not only analysing women and feminist actors, movement resources and strategies but also examining national contexts and institutional frameworks to see how they enhance or circumscribe opportunities to shape policies. Explanatory frameworks have centred on the existence of countermovements, the relative strength of left, centre, and right political parties, the partisan composition of the government, policy legacies, and state structures. Religion as an organized political force and state-church relations have also been identified as decisive factors (O'Connor et al. 1999; Author's own, 1999; Morgan 2006).

Finally, movement politics have reflected the tensions between work and care. The first comparative examinations of countries within the same welfare regime - the liberal (O'Connor, et al. 1999) and the social democratic countries (Author's own, 1999) - found major policy differences within each regime cluster that were related to differing priorities of the women's movements with respect to measures favouring women as workers or carers. This underlines that movement priorities are a critical variation in gender politics (Ferree 2012), which also represents a serious pitfall when generalizing movement influence in a specific policy area across countries.

\section{Avenues for future research}

Feminist efforts to bring gender into comparative welfare state analysis have produced important conceptual and theoretical innovations and fundamentally changed both feminist and mainstream conceptions of the welfare state. Feminist emphasis on care counterbalanced its neglect in mainstream welfare state analysis, but also heightened divisions among feminists. In particular, feminists emphasizing independence saw women's access to paid work as the key. For them, care was problematic; it put a brake on women's labour market participation and reinforced the traditional division of labour in the family. The current political emphasis in many western countries on paid work as an obligation of citizens might have also contributed to shift the balance of this debate, but it has also enriched feminist theorizing on social citizenship and spurred feminists to develop normative visions-combining care and paid work on equal grounds (Fraser, 1994; Lister, 1997; Siim, 2000). However, these visions can advance gender equality only to the extent that they incorporate differences in and between women, and the intersection with class, ethnicity, migration status, age and other social relations of inequality.

The overarching importance assigned to gender divisions in society has tended to suppress differences within the category of women in comparative feminist welfare state analyses. Nonetheless, considerations of intersectionality are present in feminist theorizing on welfare states and social citizenship (Lister 1997; Siim and Borchorst 2017; Walby 2009; Weldon 2008), in spite of the small (but growing) number of empirical analyses on the interplay between gender and multiple inequalities in the division of welfare. Empirical studies have privileged single case studies of particular intersections - gender-class-race/ethnicity - and domains - domestic and care 
work - , while other salient divisions - in particular, disability, age and sexuality - have rarely been incorporated in gender analyses of social policies. Furthermore, comparative analyses have been rare and limited by the focus on the outcomes of intersections (Korpi et al. 2013; Saraceno and Keck, 2013), that is, the differential position of particular groups of women. In this context, the adoption of comparative approaches would be particularly valuable to disentangling the contextual and intersectional effects of inequalities in shaping the division of welfare. It is also important that future research does not limit itself to particular locations/domains or to the outcomes of intersections, but also investigates the relations between social processes, systems of power and collective mobilizations around multiple intersecting inequalities determining these differential outcomes. In order to achieve this, it is crucial that analyses incorporate the politics of intersectionality, that is, the analysis of how political strategies around inequalities interact with one another to exclude or include particular marginalized groups (Crenshaw, 1991).

Immigration is of particular relevance for gender analyses of welfare states. Not only is migration status increasingly used to limit access to social benefits across countries, but immigration has quickly become a driving issue in political debates about the future of the welfare state. While the strong focus of gender analyses on immigrant domestic and care workers (Perreñas 2001; Lutz 2008; Mahon and Robinson 2011; Williams 2017) has produced many fruitful insights, it has crowded out an examination of other gendered aspects of migration that affect vast numbers of immigrant women who are not care or domestic workers. Furthermore, the emphasis on immigrant domestic and care workers fails to consider immigrants as consumers of care services and transfers (Author's own, 2018). More generally, the exclusive focus on care and domestic workers offers little leverage in analysing gender inequalities in immigrants' social rights and participation in social programmes. In other words, what is the nature of the gender differentiation in immigrants' social entitlements across welfare states, and what are the similarities and differences with the rest of the population? The answers to these questions can help us establish whether a new set of gender inequalities is emerging.

Finally, a number of research gaps stand out in the area of the analysis of welfare state change. Work on policy change has generally dealt with relatively short spans of time, often limited to the effects of particular governments. Rarely, have we seen the adoption of a long-term perspective which could also reveal the degree of robustness of policy logics underpinning the concepts of welfare state and gender policy regimes respectively (Author's own, 2017). This approach would be especially useful in evaluating the impact of major cutbacks during the past three decades on the gender division of welfare. A second issue concerns the failure to analyse from a gender perspective the impact of the interaction between changes in the economy -such as the growing precarization of labour markets -, and political decisions that have enlarged the importance of paid work as basis of entitlement to social benefits. Moreover, the coming application of artificial intelligence and robotization of a growing number of jobs challenges the sustainability and wisdom of work performance as the predominant principle of entitlement, paving the way for the possible reconsideration of the principle of care and citizenship/residence, not to mention need, as the major bases of entitlement. 
In sum, we believe that research on gender and welfare state analysis will advance best if it addresses the challenges posed by intersectionality, immigration and gender implications of longterm change of welfare states. Nonetheless, perhaps the greatest challenge that cuts across all these issues is the need to provide a balanced attention to care and paid work in feminist analyses of welfare states. 


\section{References}

An, M. Y. and Peng, I. (2016) 'Diverging Paths? A Comparative Look at Childcare Policies in Japan, South Korea and Taiwan', Social Policy \& Administration, vol 50, no 5, pp. 540-558.

Anttonen, A. and Sipilä, J. (1996) 'European social care services: Is it possible to identify models?', Journal of European social policy, vol 6, no 2, pp 87-100.

Béland, D. and Mahon, R. (2016) Advanced introduction to social policy, Cheltenham/Northampton: Edward Elgar Publishing.

Bettio, F. and Plantega, J. (2008) 'Comparing care regimes in Europe', Feminist economics, vol 10 , no 1 , pp 85-113.

Bock, G. and Thane, P. (eds) (1991) Maternity and gender policies: Women and the rise of the European welfare states, 1880s-1950s, London: Routledge.

Blofield M. and Franzoni J. M. (2015) 'Maternalism,co-responsibility, and social equity: A typology of work-family policies’, Social politics, vol. 22, no. 1, pp. 38-59.

Brennan D., Cass B., Himmelweit S. and Szebehely M. (2012) 'The marketization of care: Rationales and consequences in Nordic and liberal care regimes', Journal of European social policy, vol 22, no 4, pp 377-391.

Chau, R. C. M. and Yu, S. W. K. (2013) 'Defamilisation of twenty-two countries: Its implications for the study of East Asian welfare regime', Social policy and society, vol 12, no 3, pp 355-367.

Crenshaw, K. (1991) 'Mapping the margins: Intersectionality, identity politics, and violence against women of color', Stanford law review, vol 43, no 6, pp 1241-1299.

Crompton, R. (ed.) (1999) Restructuring gender relations and employment: The decline of the male breadwinner, Oxford: Oxford University Press.

Daly, M. (2011) 'What adult worker model? A critical look at recent social policy reform in Europe from a gender and family perspective’, Social politics, vol 18, no 1, pp 1-23.

Daly, M. and Lewis, J. (2000), 'The concept of social care and the analysis of contemporary welfare states', The British journal of sociology, vol. 51, no. 2, pp 281-298

Duncan, S. and R. Edwards (1999) Lone mothers, paid work and gendered moral rationalities, Basingstoke: Macmillan.

Esping-Andersen, G. (1990) The three worlds of welfare capitalism, Cambridge: Polity Press. 
Esping-Andersen, G. (1999) Social foundations of postindustrial economies, Oxford: Oxford University Press.

Evers, A., Pilj, M. and Ungerson, C. (eds) (1994) Payments for care. A comparative overview, Aldershot: Avebury.

Farris, S. R. and Marchetti, S. (2017) 'From the commodification to the corporatization of care: European perspectives and debates', Social politics, vol 24, no 2, pp 109-131.

Ferree, M. M. (2012) Varieties of feminism: German gender politics in global perspective. Stanford, CA: Stanford University Press.

Fish, J. and Shumpert, M. (2017) 'The grassroots-global dialect: International policy as an anchor for domestic worker organization', in S. Michel and I. Peng (eds) Gender, migration and the work of care, Springer International, pp 217-44.

Fraser, N. (1994) “After the family wage: Gender equity and the welfare state.” Political Theory, vol 22, no 4, pp 591-618.

Fraser, N. (1997) Justice interruptus: Critical reflections on the "postsocialist" condition, New York: Routledge.

Gornick, J. C. and Meyers, M. K. (eds) (2009) Gender equality: transforming family divisions of labor. New York: Verso.

Hernes, H. (1987) Welfare state and women power: Essays in state feminism, Oslo: Norwegian University Press.

Hobson, B. (ed.) (2013) Worklife balance: The agency and capabilities Gap. Oxford: Oxford University Press.

Iversen, T. and Rosenbluth, F. (2010) Women, work and politics: The political economy of gender inequality, New Haven: Yale University Press.

Javornik, J. (2014) 'Measuring state de-familialism: Contesting post-socialist exceptionalism', Journal of European social policy, vol 24, no 3, pp 240-257.

Javornik, J. and Kurowska, A. (2017) 'Work and care opportunities under different parental leave systems: Gender and class inequalities in northern Europe', Social policy \& administration, vol. 51, no. 4, pp. 617-637.

Jenson, J. (1997) 'Who cares? Gender and welfare regimes', Social politics, vol 4, no 2, pp 182 187.

Kantola, J. (2010) Gender and the European Union, Basingstoke: Palgrave Macmillan. 
Knijn, T. and Kremer, M. (1997) 'Gender and the caring dimension of welfare states: Toward inclusive citizenship', Social politics, vol 4, no 3, pp 328-361.

Korpi, W. (1980) 'Social policy and distributional conflict in the capitalist democracies', West European politics, vol 3, no 3, pp 296-316.

Korpi, W., Ferrarini, T. and Englund, S. (2013) 'Women's opportunities under different family Policy constellations: Gender, class, and inequality tradeoffs in western countries re-examined', Social politics, vol 20, no 1, pp 1-40.

Koven, S. and Michel, S. (eds) (1993) Mothers of a new world: Maternalist politics and the origins of welfare states, NY: Routledge.

Kurowska, A. (2016) '(De)familialization and (de)genderization - Competing or complementary perspectives in comparative policy analysis?', Social policy \& administration, DOI: $10.1111 /$ spol.12272.

Leitner, S. and Lessenich S. (2007) '(In)dependence as dependent variable: conceptualizing and measuring defamilialization', in J. Clasen and N.A. Siegel (eds) Investigating welfare state change, Cheltenham: Edward Elgar.

León, M. (2014) (eds) The transformation of care in European societies, London: Palgrave Macmillan.

Lewis, J. (1992) 'Gender and the development of welfare regimes', Journal of European social policy, vol 2, no 3, pp 159-173.

Lewis, J. and Giullari, S. (2005) 'The adult worker model family, gender equality and care: the search for new policy principles and the possibilities and problems of a capabilities approach', Economy and society, vol 34, no 1, pp 76-104.

Lister, R. (1997) Citizenship: feminist perspectives. London: Macmillan Press.

Lutz, H. (ed.) (2008) Migration and domestic work: A European perspective on a global theme, Aldershot: Ashgate.

Mahon, R. and Robinson, F. (eds) (2011) Feminist ethics and social policy: Towards a new global political economy of care, Vancouver, BC: University of British Columbia Press.

Marshall, T. H. (1950) Citizenship and social class, Cambridge: Cambridge University Press.

Michel, S. and Peng, I. (2012) 'All in the family? Migrants, nationhood, and care regimes in Asia and North America', Journal of European Social Policy, vol 22, no 4, pp 406-418.

Misra, J. (2003) 'Women as agents in welfare state development: A cross-national analysis of family allowance adoption', Socio-economic review, vol. 1, no 1, pp 185-214. 
Morgan, K. J. (2006) Working mothers and the welfare state: Religion and the politics of workfamily policies in western Europe and the United States, Stanford: Stanford University Press.

Nelson, B. (1990) 'The origins of the two-channel welfare state: workman's compensation and mothers' aid', in L. Gordon (ed.), Women, the state, and welfare, Madison: University of Wisconsin Press, pp 123-51.

O'Connor, J. S. (1993) 'Gender, class and citizenship in the comparative analysis of welfare state regimes: theoretical and methodological issues', British journal of sociology, vol 44, no 3, pp 50118.

O'Connor, J. S., Orloff, A. S. and Shaver, S. (1999) States, markets, families: Gender, liberalism, and social policy in Australia, Canada, Great Britain, and the United States. Cambridge: Cambridge University Press.

Orloff, A. S. (1993) 'Gender and the social rights of citizenship: The comparative analysis of state policies and gender relations', American sociological review, vol 58, no 3, pp 303-28.

Orloff, A. S. (2009a) 'Gendering the comparative analysis of welfare states: An unfinished agenda', Sociological theory, vol 27, no 3, pp 317-343.

Orloff, A. S. (2009b) 'Should feminists aim for gender symmetry? Why a dual-earner/dualcaregiver society is not every feminist utopia', in J. C. Gornick, and M. K. Meyers (eds) Gender equality: Transforming family divisions of labor, New York: Verso, pp 129-157.

Orloff, A. S. and Palier, B. (2009) 'The power of gender perspectives: Feminist influence on policy paradigms, social science, and social politics', Social politics, vol 16, no 4, pp 405-412.

Pateman, C. (1988) 'The patriarchal welfare state', in A. Gutmann (ed.) Democracy and the welfare state, Princeton: Princeton University Press, pp 231-60.

Pearce, D. M. (1978) 'The feminization of poverty: women, work and welfare', Urban and social change review, vol 11, no 1-2, pp. 28-36.

Peattie, L. and Rein, M. (1983) Women's claims: A study in political economy, Oxford: Oxford University Press.

Perreñas, R. S. (2001) Servants of globalization: Women, migration and domestic work, Stanford: Stanford University Press.

Razavi, S. (2007) The Political and Social Economy of Care in a Development Context, Geneva: UNSRID.

Robeyns, I. (2005) 'The capability approach: a theoretical survey', Journal of human development, vol 6, no 1, pp 93-117. 
Rubery, J. (2015) 'Regulating for gender equality: A policy framework to support the universal caregiver vision', Social politics, vol 22, no 4, pp 513-538.

Saraceno, C. (2010) 'Social inequalities in facing old-age dependency: a bi-generational perspective', Journal of European social policy, vol 20, no 1, pp 32-44.

Saraceno, C. and Keck, W. (2013) 'The impact of different social-policy frameworks on social Inequalities among women in the European Union: The labour-market participation of mothers', Social politics, vol 20, no 3, pp 297-328.

Saraceno, C. (2016) 'Varieties of familialism: Comparing four southern European and East Asian welfare regimes', Journal of European social policy, vol 26, no.4, pp 314-326.

Sen, A. (1992) Inequality re-examined, Oxford: Clarendon Press.

Shaver, S. (1994) "Body rights, social rights and the liberal welfare state", Critical social policy, vol 13, no 39, pp 66-93.

Siim, B. (2000) Gender and citizenship: Politics and agency in France, Britain and Denmark, Cambridge: Cambridge University Press.

Siim, B. and Borchorst, A. (2017) 'Gendering European welfare states and citizenship: Revisioning inequalities' in P. Kennett and N. Lendvai-Bainton (eds) Handbook of European social policy, Cheltenham: Edward Elgar, pp 60-74.

Skocpol, T. (1992) Protecting soldiers and mothers: The political origins of social policy in the United States, Cambridge: The Belknap Press of Harvard University Press.

Tronto, J. (1993) Moral boundaries: A political argument for an ethic of care, New York: Routledge.

Walby, S. (2009) Globalization and Inequalities, London: Sage.

Weldon, S. L. (2008) 'Intersectionality', in G. Goertz and A. Mazur (eds), Politics, gender, and concepts: Theory and methodology, Cambridge: Cambridge University Press.

Wikander, U., Kessler-Harris, A. and Lewis, J. (eds) (1995) Protecting women: Labor legislation in Europe, the United States, and Australia, 1890-1920, Urbana: University of Illinois Press.

Williams, F. (2011) 'Towards a transnational analysis of the political economy of care' in R. Mahon and F. Robinson (eds) Feminist ethics and social policy, Vancouver, BC: University of British Columbia Press, pp 21-38.

Williams, F. (2017) 'Intersections of migrant care work: An overview', in Sonya Michel and Ito Peng (eds) Gender, migration, and the work of care, DOI 10.10077/978-3-319-55086-2_2 
Williams, F. and Gavanas, A. (2008) 'The intersection of childcare regimes and migration regimes: A three-country study', in H. Lutz (ed.) Migration and domestic work: A European perspective on a global theme, Aldershot: Ashgate, pp 13-28.

Wilson, E. (1977) Women and the welfare state. London: Tavistock.

Yu, S., Chau, C. M. and Lee, K. M. (2015) 'Using defamilisation typologies to study the

Confucian welfare regime', Journal of international and comparative social policy, vol 31, no 1, pp. 74-93. 